\title{
ANALYSIS OF THE EFFECT OF SYSTEM QUALITY, INFORMATION QUALITY, SERVICE QUALITY, PROCESS QUALITY, AND COLLABORATION QUALITY TO USEFULNESS, USER SATISFACTION, AND CUSTOMER LOYALTY OF SOCIOLLA APPLICATION CUSTOMER IN SURABAYA
}

\author{
${\text { Desia Kumalasaria*, }{ }^{\mathrm{a}} \text { Amelia }^{\mathrm{b}} \text {, Oliandes }}^{\mathrm{c}}$ \\ adesiakumalasari26@gmail.com \\ ${ }^{a}$ Master of Management Student at Pelita Harapan University, Surabaya 60234, Indonesia \\ ${ }^{b, c}$ The Lecturer of Master of Management at Pelita Harapan University, Surabaya 60234, Indonesia
}

\begin{abstract}
In this era, technology is important and very much needed, because almost all systems are operated online. The number of internet users in Indonesia according to the Central Statistics Agency (BPS) in 2018 was 171.17 million users. The increasing number of internet users in Indonesia today is one of the reasons for the emergence of e-commerce. Sociolla is one of an e-commerce platform in the beauty sector originating from Indonesia which uses B2C business model it offers beauty products which was ranked the 8th most visitors dekstop version in 2018 with 3 million visitors per month. Sociolla has now upgraded its system by launching a new application, namely SOCO, to make online shopping even easier. Therefore, the presence of Sociolla application was very influential in the development of the e-commerce industry, especially in Surabaya. The results showed that service quality has a significant effect on usefulness with a regression coefficient of 0.236 , service quality has a significant effect on user satisfaction with a regression coefficient of 0.153 , system quality has a significant effect on usefulness with a regression coefficient of 0.212 , system quality has a significant effect on user satisfaction with a regression coefficient of 0.151 , collaboration quality has a significant effect on usefulness with a regression coefficient of 0.188 , collaboration quality has a significant effect on user satisfaction with a regression coefficient of 0.178 , process quality has a significant effect on usefulness with a regression coefficient of 0.182 , process quality has a significant effect on user satisfaction with a regression coefficient of 0.213 , information quality has a significant effect on usefulness with a regression coefficient of 0.153 , information quality has a significant effect on user satisfaction with a regression coefficient of 0.132 , usefulness has a significant effect on user satisfaction with a regression coefficient of 0.212 , usefulness has a significant effect on customer loyalty with a regression coefficient of 0.213 , and user satisfaction has a significant effect on customer loyalty with a regression coefficient of 0.625 .
\end{abstract}

Keywords: System Quality, Information Quality, Service Quality, Process Quality, Collaboration Quality, Usefulness, User Satisfaction, Customer Loyalty

\section{Introduction}

In this era, technology is important and very much needed, because almost all systems are operated online. This very rapid development of technology can change the behavior and attitudes of the community in terms of online purchasing. The number of internet users in Indonesia according to the Central Statistics Agency (BPS) in 2018 was 171.17 million users. The increasing number of internet users in Indonesia today is one of the reasons for the emergence of e-commerce. CupoNation Indonesia said that Indonesians prefer shopping online via mobile rather than desktop, with $77.15 \%$ of visitors via the mobile web and only $22.85 \%$ via desktop. This 
shows that almost all shoppers in Indonesia prefer online shopping using smartphones rather than desktop. (https://www.cnnindonesia.com, downloaded on May 26, 2020).

Sociolla is one of an e-commerce platform in the beauty sector originating from Indonesia which uses B2C business model it offers beauty products which was ranked the 8th most visitors dekstop version in 2018 with 3 million visitors per month. Sociolla has now upgraded its system by launching a new application, namely SOCO, to make online shopping even easier. Therefore, the presence of Sociolla application was very influential in the development of the e-commerce industry, especially in Surabaya. In this application, visitors can become contributors or members of the community, shop, and provide product reviews in one place, SOCO is not only a community platform but also a platform review (https://swa.co.id/, downloaded on 23 June 2020).

To increase customer loyalty according to Mardalis (2005), which mentions six reasons for the importance of getting it customer loyalty, namely; the first, the more prospective customer, the cost getting new customers is much bigger than keeping and retain existing customers, customers you already trust companies in one business will believe also in other matters, costs company operations will be efficient if it has many loyal customers, companies can reduce the psychological and social costs due to this old customers have had many positive experiences with the company, the last, loyal customers will always defend the company even trying also to attract and advise others to become customers. According to Umar (2014), customer loyalty is a situation where customers consistently spend their entire budget to buy a product or service from the same seller. Loyalty can be seen through the use of Sociolla website download and application continuously by the customer, then the customer will recommend to their relatives to participate in downloading the website or application from Sociolla, and stick with the negative issues out there.

\section{Litterature Review}

\subsection{Theories}

\subsubsection{Customer Loyalty}

According to Oliver (2010), defining customer loyalty is a long-lasting commitment by consumers to resubscribe or continuously re-purchase specified products or services in the future, even when the effect of the situation and the marketing activities are likely to trigger behavior change. Umar said the same thing (2014) that customer loyalty is a situation where customers constantly spend the entire existing budget on purchasing a product or service from the same vendor.

\subsubsection{Usefulness}

Usefulness is the extent at which someone feels that the use of a particular subject could enhance the efficiency of the person at work (Machmud, 2018). According to Gurinting and Ndubisi (2006), it directly connects perceived usefulness to productivity. This shows using computers in the workplace will increase user productivity, increase performance, increase job quality and will be beneficial in the workplace.

\subsubsection{User Satisfaction}

User satisfaction is the reaction and feedback created by users using the information system (Machmud, 2018). According to Daryanto and Setyobudi (2014) customer satisfaction is described as one of the most important indicators of a company's performance, if the customer is satisfied with the product or service, the customer will positively evaluate the company's expectations, but if the customer is not satisfied, the customer will be 
dissatisfied and complained.

\subsubsection{Collaboration Quality}

According to Urbach, et al. (2010) describe that the collaboration quality requires the quality of employee collaboration portal support among its users. Collaboration quality is one factor that needs to be well handled and continually enhanced to ensure equal and effective collaboration between the stakeholders involved. (Yan dan Dooley, 2014).

\subsubsection{Process Quality}

According to Chen, et al. (2013) process quality involves how the service is ultimately delivered and how the user interface is formed. Meanwhile, according to Al-Mudimigh (2007) defines the process quality, including the business process and a sequence of interrelated operations, which, when performed, generate output that adds value from the customer's point of view.

\subsubsection{Service Quality}

Service quality is a method of measurement of the level of service delivered by a company (Pramana and Rastini, 2016). According to Gilbert, et al. (2004), service quality allows consumers to devote themselves to the products and services of a company in order to impact growing the market share of the product.

\subsubsection{Information Quality}

Information quality is defined by the amount of messages measurement and information processing processes that are involved within the company (Barua and Ravindran, 1996). Meanwhile, according to Risdyanto, et al (2018), the consistency of information is the degree to which information will consistently fulfill the needs and expectations of all people who need this information by implementing their processes.

\subsubsection{System Quality}

According to Popoola et al. (2014), defined system quality as a reference to a system owned by a corporation that can regulate the quality of services for products and services. According to Yousuf and Wahab (2017), system quality is the overall system quality, and is also the most common dimension, as long as the information system is analyzed, inadequate system quality will make consumers believe that the service provider has not made adequate efforts.

\subsection{Hypotheses}

H1: System Quality has a significant effect on Usefulness

H2: System Quality has a significant effect on User Satisfaction

H3: Information Quality has a significant effect on Usefulness

H4: Information Quality has a significant effect on User Satisfaction

H5: Service Quality has a significant effect on Usefulness

H6: Service Quality has a significant effect on User Satisfaction

H7: Process Quality has a significant effect on Usefulness

H8: Process Quality has a significant effect on User Satisfaction 
H9: Collaboration Quality has a significant effect on Usefulness

H10: Collaboration Quality has a significant effect on User Satisfaction

H11: Usefulness has a significant effect on User Satisfaction

H12: Usefulness has a significant effect on Customer Loyalty

H13: User Satisfaction has a significant effect on Customer Loyalty

\subsection{Research Model}

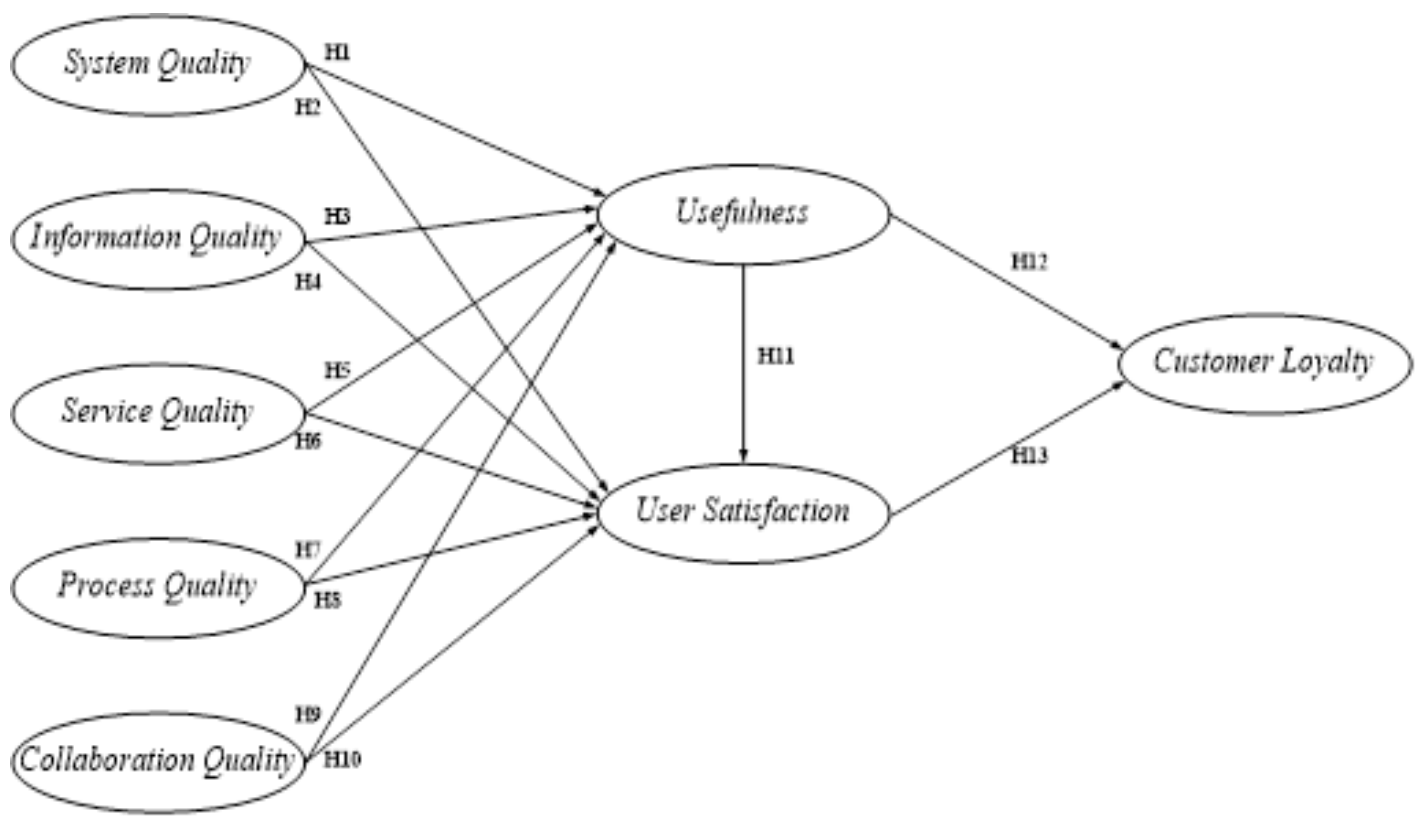

Figure 1: The Framework of Research Model

Based on previous study Chen, et al., (2013) in this study there are eight variables, System Quality, Information Quality, Service Quality, Process Quality, Collaboration Quality, Usefulness, User Satisfaction and Customer Loyalty.

\section{Research Methods}

This research is causal research, because it is used to develop existing research models to test the research hypotheses that are determined based on literature review to answer the problems identified in the previous chapter. The research method used in this study is a quantitative method, where this method is a scientific approach to managerial and economic decision making. The method used in this study will refer to references that can carry out a simultaneous analysis process associated with a multi-variable research model, the Linier Regression. The program used is the SPSS 25.0 software program. This chapter describes the object of research directed at analyzing models about the effect of system quality, information quality, service quality, process quality, and collaboration quality to usefulness, user satisfaction, and customer loyalty of Sociolla application customer in Surabaya. The population that will be used in this study is customer Sociolla in Surabaya. The sampling method used in this research is non-probability sampling. This study uses a questionnaire as the main 
tool in data collection. In this study, researchers will use a Snowball Sampling. Snowball Sampling is a technique for finding research subjects in which one subject gives the researcher the name of another subject, which in turn gives the third name, and so on. The area used as a place for distributing questionnaires was the Surabaya city, so that respondents were selected according to the criteria determined in this study. The characteristics of the respondents determined are men and women aged 18-60 years where the age is an early adulthood (Kotler and Armstrong, 2010), have used Sociolla application to shop for at least the last year, have used the products you purchased using Sociolla app to shop for at least the last year, and have contacted customer service from Sociolla application in the last year. The number of variables used in this study is 8 variables, therefore the minimum number of samples needed is 100 respondents, and for this study a total of 125 respondents will be determined. Data collection is done by distributing questionnaires to respondents in accordance with the characteristics of the sample that has been described previously. After completing the questionnaire, the respondent returns the questionnaire that has been filled out and will then be selected by the researcher. The selected questionnaire is a questionnaire that is completely filled out and according to the filling instructions. After selection, the selected questionnaire will be further processed. After the data is tabulated, then the research model will be tested using SPSS software version 25.0. The questionnaire in this study will be divided into two parts. The first part contains questions to get general information about the respondent that is useful to determine the suitability of the characteristics of the respondent with the sample criteria. The second part contains several statements to obtain research data and analyze of the effect of System Quality, Information Quality, Service Quality, Process Quality, and Collaboration Quality to Usefulness, User Satisfaction, and Customer Loyalty of Sociolla Application Customer in Surabaya. The scale used in this study is a Likert Scale, where the answer is provided at intervals from 1=Strongly Disagree (STS) to 5=Strongly Agree (SS). Statements are made using a scale of 1-5 to obtain internal data.

\section{Result and Discussion}

\subsection{Assessment of Measurement Model}

Table 1: Multiple Regression Effects of System Quality, Information Quality, Service Quality, Process Quality, and Collaboration Quality to Usefulness

\begin{tabular}{|l|c|c|c|c|c|c|}
\hline \multicolumn{1}{|c|}{ Model/ Variable } & $\mathbf{R}$ & $\begin{array}{c}\text { Adj } \\
\mathbf{R}^{2}\end{array}$ & $\mathbf{F}_{\text {sig }}$ & $\begin{array}{c}\text { Standardized } \\
\text { Coefficients Beta }\end{array}$ & $\mathbf{t}_{\text {sig }}$ & Hypotheses \\
\hline $\begin{array}{l}\text { System Quality, Information } \\
\text { Quality, Service Quality, } \\
\text { Process Quality, and } \\
\text { Collaboration Quality * } \\
\text { Usefulness }\end{array}$ & 0,839 & 0,691 & 0,000 & & & \\
\hline System Quality * Usefulness & & & & 0,212 & 0,022 & Accepted \\
\hline $\begin{array}{l}\text { Information Quality * } \\
\text { Usefulness }\end{array}$ & & & & 0,153 & 0,042 & Accepted \\
\hline $\begin{array}{l}\text { Service Quality* } \\
\text { Usefulness }\end{array}$ & & & & 0,236 & 0,003 & Accepted \\
\hline $\begin{array}{l}\text { Process Quality * } \\
\text { Usefulness }\end{array}$ & & & & 0,188 & 0,019 & Accepted \\
\hline $\begin{array}{l}\text { Collaboration Quality * } \\
\text { Usefulness }\end{array}$ & & & & 0,035 & Accepted \\
\hline
\end{tabular}


Table 2: Simple Regression Effects of System Quality, Information Quality, Service Quality, Process Quality, Collaboration Quality, and Usefulness to User Satisfaction

\begin{tabular}{|l|c|c|c|c|c|c|}
\hline \multicolumn{1}{|c|}{ Model/ Variable } & $\mathbf{R}$ & $\begin{array}{c}\text { Adj } \\
\mathbf{R}^{2}\end{array}$ & $\mathbf{F}_{\text {sig }}$ & $\begin{array}{c}\text { Standardized } \\
\text { Coefficients Beta }\end{array}$ & $\mathbf{t}_{\text {sig }}$ & Hypotheses \\
\hline $\begin{array}{l}\text { System Quality, Information } \\
\text { Quality, Service Quality, } \\
\text { Process Quality, } \\
\text { Collaboration Quality, and } \\
\text { Usefulness User } \\
\text { Satisfaction }\end{array}$ & 0,898 & 0,797 & 0,000 & & & \\
\hline $\begin{array}{l}\text { System Quality * User } \\
\text { Satisfaction }\end{array}$ & & & & 0,151 & 0,048 & Accepted \\
\hline $\begin{array}{l}\text { Information Quality * User } \\
\text { Satisfaction }\end{array}$ & & & & 0,132 & 0,033 & Accepted \\
\hline $\begin{array}{l}\text { Service Quality * User } \\
\text { Satisfaction }\end{array}$ & & & & 0,153 & 0,021 & Accepted \\
\hline $\begin{array}{l}\text { Process Quality * User } \\
\text { Satisfaction }\end{array}$ & & & & 0,213 & 0,001 & Accepted \\
\hline $\begin{array}{l}\text { Collaboration Quality } * \\
\text { User Satisfaction }\end{array}$ & & & 0,212 & 0,005 & Accepted \\
\hline $\begin{array}{l}\text { Usefulness User } \\
\text { Satisfaction }\end{array}$ & & & & & \\
\hline
\end{tabular}

Table 3: Simple Regression Effects of Usefulness and User Satisfaction to Customer Loyalty

\begin{tabular}{|l|c|c|c|c|c|c|}
\hline \multicolumn{1}{|c|}{ Model/ Variable } & $\mathbf{R}$ & $\begin{array}{c}\text { Adj } \\
\mathbf{R}^{2}\end{array}$ & $\mathbf{F}_{\text {sig }}$ & $\begin{array}{c}\text { Standardized } \\
\text { Coefficients Beta }\end{array}$ & $\mathbf{t}_{\text {sig }}$ & Hypotheses \\
\hline $\begin{array}{l}\text { Usefulness and User } \\
\text { Satisfaction* Customer } \\
\text { Loyalty }\end{array}$ & 0,798 & 0,631 & 0,000 & & & \\
\hline $\begin{array}{l}\text { Usefulness * Customer } \\
\text { Loyalty }\end{array}$ & & & & 0,213 & 0,030 & Accepted \\
\hline $\begin{array}{l}\text { User Satisfaction* } \\
\text { Customer Loyalty }\end{array}$ & & & 0,625 & 0,000 & Accepted \\
\hline
\end{tabular}

Significancy value ( $\mathbf{t}_{\text {sig }}$ ) for each relationship between the variables tested are shown in table 1. Causality relationships that occur between the System Quality, Information Quality, Service Quality, Process Quality,

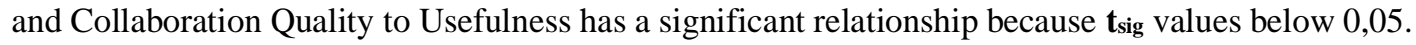

Table 2 the results of the significance value $\left(\mathbf{t}_{\text {sig }}\right)$ for each relationship between the variables tested. As for the causality relationship that occurs between the System Quality, Information Quality, Service Quality, Process Quality, Collaboration Quality, and Usefulness to User Satisfaction has a significant relationship because tsig values below 0,05.

Significancy value ( $\mathbf{t}_{\text {sig }}$ ) for each relationship between the variables tested are shown in table 3 . Causality relationships that occur between the Usefulness and User Satisfaction to Customer Loyalty has a significant relationship because $\mathbf{t}_{\text {sig }}$ values below 0,05 . 


\subsection{Hypotheses Testing}

Table 4: Summary of Testing Results.

\begin{tabular}{|l|l|}
\hline Hypotheses & Analysis \\
\hline H1: System Quality has a significant effect on Usefulness & Accepted \\
\hline H2: System Quality has a significant effect on User Satisfaction & Accepted \\
\hline H3: Information Quality has a significant effect on Usefulness & Accepted \\
\hline H4: Information Quality has a significant effect on User Satisfaction & Accepted \\
\hline H5: Service Quality has a significant effect on Usefulness & Accepted \\
\hline H6: Service Quality has a significant effect on User Satisfaction & Accepted \\
\hline H7: Process Quality has a significant effect on Usefulness & Accepted \\
\hline H8: Process Quality has a significant effect on User Satisfaction & Accepted \\
\hline H9: Collaboration Quality has a significant effect on Usefulness & Accepted \\
\hline H10: Collaboration Quality has a significant effect on User Satisfaction & Accepted \\
\hline H11: Usefulness has a significant effect on User Satisfaction & Accepted \\
\hline H12: Usefulness has a significant effect on Customer Loyalty & Accepted \\
\hline H13: User Satisfaction has a significant effect on Customer Loyalty & Accepted \\
\hline
\end{tabular}

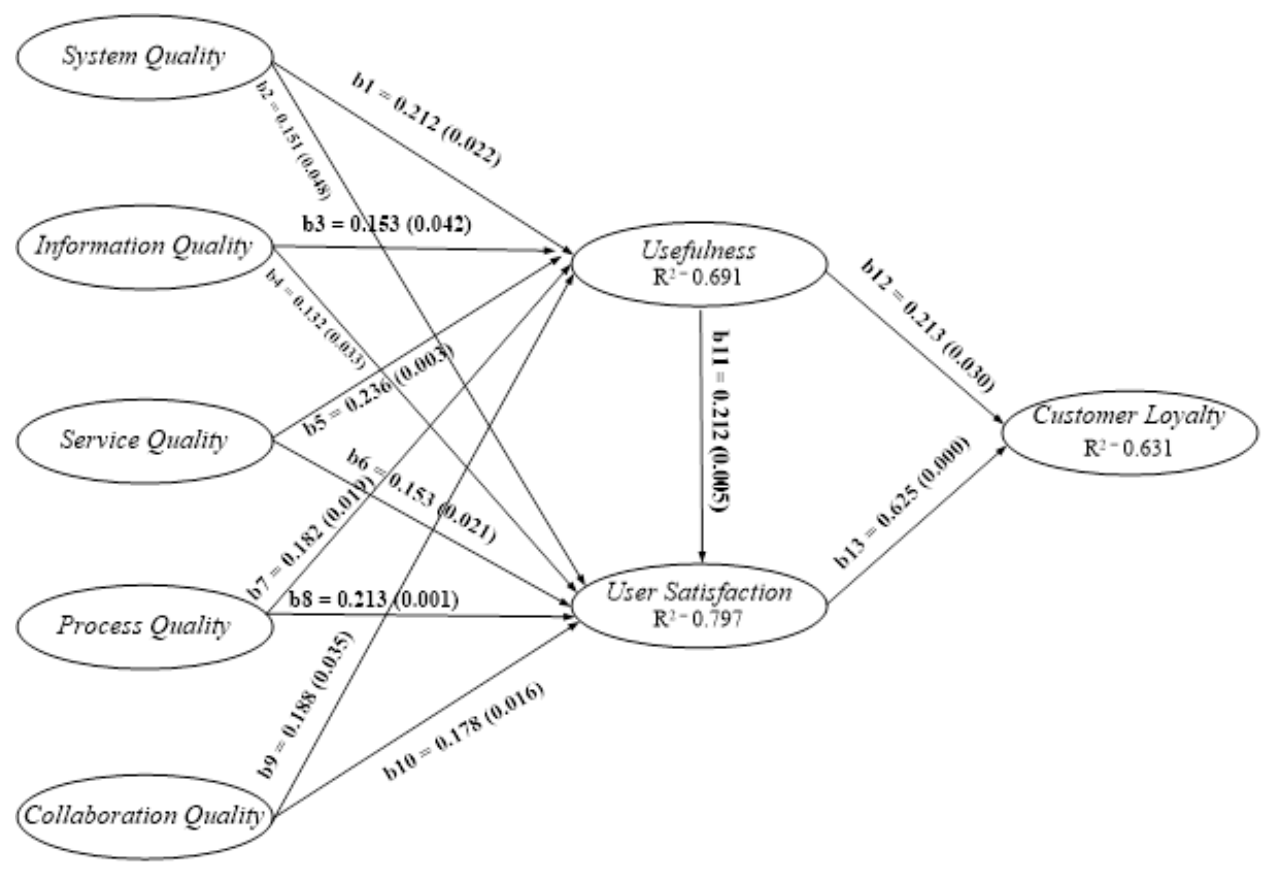

Fig. 2: The Framework of Analysis Result

\subsection{Discussion}

Based on SPSS 25.0 analysis result, estimation parameters between System Quality on Usefulness, Information Quality on Usefulness, Service Quality on Usefulness, Process Quality on Usefulness, and Collaboration Quality on Usefulness has significant relationship because $\mathbf{t}_{\text {sig }}$ values below 0,05 . It can be said 
that hypothesis H1, H3, H5, H7, and H9 were accepted (This were showed at Table 1 and Table 4). As for the estimation parameters between the System Quality on User Satisfaction, Information Quality on User Satisfaction, Service Quality on User Satisfaction, Process Quality on User Satisfaction, Collaboration Quality on User Satisfaction, and Usefulness on User Satisfaction as significant relationship because tsig values below 0,05. It can be said that hypothesis H2, H4, H6, H8, H10, and H11 were accepted (This were showed at Table 2 and Table 4). The estimation parameters between the Usefulness to Customer Loyalty and User Satisfaction to Customer Loyalty has significant relationship because tsig values below 0,05. It can be said that hypothesis H12 and H13 were accepted (This were showed at Table 3 and Table 4).

The findings of this study provide several important implications for System Quality, Information Quality, Service Quality, Process Quality, and Collaboration Quality To Usefulness, User Satisfaction, and Customer Loyalty especially in the future. User Satisfaction variable is the respondent's main concern and is the most important aspect to be addressed and developed immediately with the highest regression coefficient $=0,625$ and $\mathbf{t}_{\text {sig }}=0,000$ has a significant positive effect on Customer Loyalty. This indicates that customers are satisfied using Sociolla application because of the attractive appearance of the application and Sociolla provides satisfactory service so that customers feel satisfied and recommend to their friends because user satisfaction is categorized as affection where this affection will be attached to the customer. In addition, because of this affection, then customers who are already satisfied with Sociolla will recommend Sociolla application to friends. Process Quality is the variable that has the biggest influence in affect User Satisfaction with regression coefficient $=0,213$ and $\mathbf{t}_{\text {sig }}=0,001$ has a significant positive effect on User Satisfaction. This shows that customers are satisfied to use Sociolla application because Sociolla application can be trusted in processing products that are in accordance with customer orders, the shopping process is easy to understand and facilitates the process of finding beauty products that customers need because process quality is categorized as affection where this affection will be attached to the customer. In addition, because of this affection, customers who are already satisfied with Sociolla application will use Sociolla application to shop for beauty products. Collaboration quality is the variable that has the greatest influence second in influencing User Satisfaction with regression coefficient $=0,178$ and $\mathbf{t}_{\text {sig }}=0,016$ has a significant positive effect on User Satisfaction. This shows that customers are satisfied using Sociolla application because it is easier to find various beauty products that are difficult to find in other applications (for example: exclusive collaboration bundling and kit), increasing customer productivity in finding information about the products needed and using Sociolla application will improve customer performance by getting attractive promotions (for example: 50\% cashback to IDR 20,000 for payments using Gopay) because Collaboration Quality is categorized as an affection where this affection will stick to the customer. In addition, because of this affection, customers who are satisfied with Sociolla application will use Sociolla application to find various beauty products that are difficult to find in other applications and get attractive promos from Sociolla. Service Quality is the variable with the third biggest influence in affecting User Satisfaction with regression coefficient $=0,153$ and $\mathbf{t}_{\text {sig }}=0,021$ has a significant positive effect on User Satisfaction. This indicates that customers are satisfied to use Sociolla application because Sociolla provides the answers needed in responding to questions from customers, responding to customer questions is very responsive, and Sociolla customer service is easy to contact at all times because service quality is categorized as affection where this affection will be attached to the customer. In addition, because of this affection, then customers who are already satisfied with Sociolla application will use Sociolla application to contact Sociolla customer service. System Quality is the variable with the fourth biggest influence in affecting User Satisfaction with regression coefficient $=0,151$ and $\mathbf{t}_{\mathbf{s i g}}=0,048$ has a significant positive effect on User Satisfaction. This shows that customers are satisfied to use Sociolla application because Sociolla has a payment procedure that facilitates customers, Sociolla is an application with an easy-to-understand look, and Sociolla provides good two-way communication services because of the system quality is categorized as affection where this affection will be attached to the customer. In addition, because of this affection, customers who are already satisfied with Sociolla application will use Sociolla application to search for beauty products. 
Information Quality is the variable with the fifth biggest influence in affecting User Satisfaction with regression coefficient $=0,132$ and $\mathbf{t}_{\text {sig }}=0,033$ has a significant positive effect on User Satisfaction. This indicates that customers are satisfied to use Sociolla application to provide complete information on the details of beauty products needed by customers, provide useful product information in making it easier to choose products that suit customers' needs, and provide quality information in connection with the variations needed because information quality is categorized as affection where this affection will be attached to the customer. In addition, because of this affection, customers who are already satisfied with Sociolla application will use Sociolla application to find information on beauty products and choose products that suit customers' needs.

Usefulness is the second-largest influential variable in shaping customer loyalty with regression coefficient $=0,213$ and $\mathbf{t}_{\text {sig }}=0,030$ has a significant positive effect on Customer Loyalty. This shows that customers feel Sociolla can make it easier to find their needs in Sociolla application with the features provided by Sociolla so that customers will continue to use the application and make Sociolla the first choice. Usefulness variable has a big role in influencing User Satisfaction with regression coefficient $=0,212$ and $\mathbf{t}_{\text {sig }}=0,005$ has a significant positive effect on User Satisfaction. This indicates that customers are satisfied with the appearance of Sociolla application, Sociolla services are satisfactory and satisfied using Sociolla application as a whole which is useful in saving time to find information about beauty products can and save shipping costs.

Usefulness variables are variables that are influenced the most by Service Quality. The result of regression coefficient $=0.236$ and $\mathbf{t}_{\text {sig }}=0,003$ has a significant positive effect on Usefulness. This shows that using Sociolla application can facilitate customers because Sociolla provides the answers needed in responding to questions from customers, responds to customer questions are very responsive, and Sociolla customer service is easy to contact at any time because Service Quality is categorized as an affection where this affection will be attached to the customer. In addition, due to this affection, customers who have been facilitated with Sociolla application will use Sociolla application to contact Sociolla customer service.

Usefulness variables are the second-largest influenced variables by system quality variables with a regression coefficient of 0.212 and $\mathbf{t}_{\text {sig }}=0,022$ has a significant positive effect on Usefulness. This shows that using Sociolla application can facilitate customers because Sociolla has a payment procedure that facilitates customers, Sociolla is an application with an easy-to-understand look, and Sociolla provides good two-way communication services because system quality is categorized as affection where this affection will be attached to the customer. In addition, because of this affection, customers who have been facilitated with Sociolla application will use Sociolla application to search for beauty products.

Usefulness variables are the third largest influenced variables by Collaboration Quality with a regression coefficient of 0.188 and $\mathbf{t}_{\text {sig }}=0,035$ has a significant positive effect on Usefulness. This shows that using Sociolla application can make it easier for customers because it is easier to find various beauty products that are difficult to find in other applications (for example: exclusive collaboration bundling and kit), increasing customer productivity in finding information about the products needed and using Sociolla application will improve customer performance by getting attractive promotions (for example: $50 \%$ cashback to IDR 20,000 for payments using Gopay) because Collaboration Quality is categorized as an affection where this affection will stick to the customer. In addition, because of this affection, then customers who have been facilitated with Sociolla application will use Sociolla application to find various beauty products that are difficult to find in other applications and get attractive promos from Sociolla.

Usefulness variables are the fourth largest influenced variables by Process Quality. As for the result of the regression coefficient of 0.182 and $\mathbf{t}_{\text {sig }}=0,019$ has a significant positive effect on Usefulness. This shows using Sociolla application can facilitate customers because Sociolla application can be trusted in processing products in accordance with customer orders, the shopping process is easy to understand and facilitates the process of finding beauty products needed by customers because Process Quality is categorized as an affection where this affection will be attached to the customer.In addition, because of this affection, customers who have been 
facilitated with Sociolla application will use Sociolla application to shop for beauty products.

Usefulness variables are the fifth largest influenced variables by Information Quality with a regression coefficient of 0.153 and $\mathbf{t}_{\text {sig }}=0,042$ has a significant positive effect on Usefulness. This shows that using Sociolla application can facilitate customers because Sociolla provides complete information about the details of beauty products needed by customers, provides useful product information in facilitating the choice of products that suit customers' needs, and provides quality information in connection with the variations needed because Information Quality is categorized as affection where this affection will be attached to the customer. In addition, because of this affection, customers who have been facilitated with Sociolla application will use Sociolla application to find information on beauty products and choose products that suit customers' needs.

\section{Conclusion}

This study provides evidence that System Quality significantly influences Usefulness, Information Quality significantly influences Usefulness, Service Quality significantly influences Usefulness, Process Quality significantly influences Usefulness, Collaboration Quality significantly influences Usefulness, System Quality significantly influences User Satisfaction, Information Quality significantly influences User Satisfaction, Service Quality significantly influences User Satisfaction, Process Quality significantly influences User Satisfaction, Collaboration Quality significantly influences User Satisfaction, Usefulness significantly influences User Satisfaction, Usefulness significantly influences Customer Loyalty, and User Satisfaction significantly influences Customer Loyalty.

\subsection{Managerial Implications}

Table 5: Managerial Implications

\begin{tabular}{|l|l|}
\hline \multicolumn{1}{|c|}{ Current Research } & \multicolumn{1}{c|}{ Managerial Implications } \\
\hline System Quality & $\begin{array}{l}\text { Develop a special Sociolla e-wallet service that makes it easy for } \\
\text { customers to process payments in such a way that they do not need to } \\
\text { make payments to mobile banking, ATMs, mini-market outlets and so } \\
\text { on. }\end{array}$ \\
\begin{tabular}{|l} 
Create an enticing main menu and include information about each icon \\
in the Sociolla application so that potential users can be involved in \\
using the Sociolla application for a long time and will not be confused \\
with current icons so that they can encourage new users to use the \\
Sociolla application and buy on the Sociolla application. \\
Develop two-way communication services to Sociolla application \\
users by ensuring that it addresses consumer complaints in less than 30 \\
minutes, so that customers do not wait too long for Sociolla to respond.
\end{tabular} \\
\hline Information Quality & $\begin{array}{l}\text { Provides related product suggestions by offering selected products } \\
\text { according to customer needs, such as customers searching for the } \\
\text { product A then Sociolla automatically recommends the product B and } \\
\text { the product C that customers would prefer so that they can pick the } \\
\text { products recommended by Sociolla. } \\
\text { Provides some of the latest information, such as beauty hacks, about } \\
\text { how to conduct beauty treatments at home during a pandemic. } \\
\text { Provide any tips for the latest products that are currently on the trend } \\
\text { by adjusting customer demand. }\end{array}$ \\
\hline
\end{tabular}




\begin{tabular}{|c|c|}
\hline Service Quality & $\begin{array}{l}\text { - Improve current customer service, such as developing a fast-track } \\
\text { feature that can recognise the issues that appear with the Sociolla } \\
\text { application, and customers that may have problems so that they can } \\
\text { help with the problems that emerge with the customer application. } \\
\text { Employing workers who have experience of the field of beauty or who } \\
\text { can offer training/training to employees who are Sociolla Customer } \\
\text { Service, so that they can answer all questions and provide product } \\
\text { reviews according to customer's skin type. } \\
\text { Optimising recruitment of Sociolla, in particular those with experience } \\
\text { in the beauty industry, so that employees of Sociolla who are a } \\
\text { customer service provider have up-to-date knowledge on the world of } \\
\text { beauty. }\end{array}$ \\
\hline Process Quality & $\begin{array}{l}\text { - Improve the method of shopping for beauty products from different } \\
\text { brands according to customer preferences in order to make it easy for } \\
\text { customers to select products that match their needs. } \\
\text { - Give the details in the Sociolla application, specifically by converting } \\
\text { rupiah units to US dollars for overseas customers. } \\
\text { Increase the quality of the product process by doing so on the day of } \\
\text { check-out by re-checking whether the product order purchased by the } \\
\text { customer is suitable because there are a variety of customer reports } \\
\text { about the Sociolla application that state that their order is not adequate. }\end{array}$ \\
\hline Collaboration Quality & $\begin{array}{l}\text { - Adding cash back or exclusive vouchers to Sociolla customers that } \\
\text { have } 5000 \text { SOCO Points, such as partnering with a beauty clinic. } \\
\text { - Added product bundling packages that might not be available on most } \\
\text { e-commerce platforms. } \\
\text { - Partnering with other companies in the technology field to develop an } \\
\text { additional feature that can automatically identify faces that only appear } \\
\text { in the Sociolla application. }\end{array}$ \\
\hline Usefulness & $\begin{array}{l}\text { - Improve logistics operations by including expeditions that can save } \\
\text { shipping costs so that customers can conveniently select an expedition } \\
\text { with more competitive shipping costs and add items that are currently } \\
\text { on the trend, such as beauty products from Pyukang Yul, Hadalabo and } \\
\text { other brands that are not currently available on the Sociolla application. } \\
\text { - Updating the Sociolla application regularly and innovating by offering } \\
\text { the latest features, such as including an automated face recognition } \\
\text { tool, which can show customer's skin type and offer product } \\
\text { recommendations. } \\
\text { Adding a variety of discounts to customers who have } 5000 \text { SOCO } \\
\text { Points by providing free holiday vouchers or beauty treatment vouchers } \\
\text { at certain clinics. }\end{array}$ \\
\hline User Satisfaction & $\begin{array}{l}\text { - Increase the speed of loading apps that have been taking a little longer } \\
\text { so that users have to wait a few seconds to launch the Sociolla } \\
\text { application. } \\
\text { - Reviewing resources in response to customer feedback, i.e. adding } \\
\text { customer service contacts such as a line or WhatsApp that will respond } \\
\text { to any current customer complaints in order to make it easy for }\end{array}$ \\
\hline
\end{tabular}




\begin{tabular}{|l|l|}
\hline & $\begin{array}{l}\text { consumers to engage with Sociolla services besides communicate with } \\
\text { the Sociolla application. } \\
\text { Revived appearance and features such as icons such as Christmas or } \\
\text { New Year themes in the application. }\end{array}$ \\
\hline Customer Loyalty & $\begin{array}{l}\text { Offer enticing promotions such as free vouchers that will enthuse } \\
\text { customers with these promotions so that customers can make purchases } \\
\text { on the Sociolla application in order to receive these promotions in the } \\
\text { expectation that customers can still be committed to Sociolla, making } \\
\text { Sociolla the first choice for shopping. } \\
\text { Adding the number of beauty products available in Sociolla with the } \\
\text { support of the automated face detection feature, so customers can still } \\
\text { shop on the Sociolla app daily and under the product needs suggested } \\
\text { by Sociolla based on the skin type of the consumer. } \\
\text { Adding an automated face recognition system that can identify the skin } \\
\text { type of the customer hoping the customer can recommend to friends or } \\
\text { relatives that they download and purchase in the Sociolla application } \\
\text { so this feature supports the opportunity to recommend items according } \\
\text { to the skin type of the customer. }\end{array}$ \\
\hline
\end{tabular}

\subsection{Recommendation}

- Looking at the limitations regarding the research object that only takes respondents, namely Sociolla customers in Surabaya, it is expected that the next research using the same model or modified can be applied to different objects to get more general results against factors that affect customer loyalty.

- Further research is expected to complement the existing variables in this study so as to further improve the understanding of factors that affect customer loyalty, such as the addition of product quality variables, experience, repurchase intention and others.

- Further research can be developed by linking factor factors that affect customer loyalty based on income level, age, and gender. Future research can also expand the scope of the reponden to be researched, or conduct its research in different areas with the research that has been done today, so that the follow-up research carried out increasingly gives a broad picture of customer loyalty.

\section{References}

Al-Mudimigh, A. S. (2007). The Role And Impact Of Business Process Management In Enterprise. Business Process Management Journal, $13(6), 866-874$.

Barua, A., \& Ravindran, S. (1996). Reengineering Information Sharing Behaviour In Organizations. Journal Of Information Techn ology, 11(3), 261-272.

Chen, J. V., Chen, Y., \& Capistrano, E.P. (2013). Process Quality And Collaboration Quality On B2B E-commerce. Industrial Management \& Data Systems, 113, 908-926.

Cnnindonesia.com (2020, 25 Januari). Daftar Toko Online yang Paling Menguasai Pasar RI Selama 2019. Diakses pada 26 Mei 2020, dari https://www.cnnindonesia.com/teknologi/20200124205259-206-468540/daftar-toko-online-yang-paling-menguasai-pasar-riselama-2019.

Daryanto, \& Setyobudi, I. (2014). Konsumen Dan Pelayanan Prima. Yogyakarta: Gava Media.

Gilbert, G. R., Veloutsou, C., Goode, M. M., \& Moutinho, L. (2004). Measuring Customer Satisfaction In The Fast Food Industry: A CrossNational Approach. The Journal Ofservices Marketing.

Guriting, P., \& Ndubisi , N. O. (2006). Borneo Online Banking: Evaluating Customer Perceptions And Behavioural Intention. Management Research News, 29(1/2), 6-15.

Kotler, P., \& Keller, K. L. (2012). Marketing Management. Essex: Pearson Education Inc.

Machmud, R. (2018). Kepuasan Penggunaan Sistem Informasi (Studi Kasus Pada T3-Online). Gorontalo. 
Oliver, R. L. (2010). Satisfaction: A Behavioral Perspective On The Consumer. New York: Mcgraw-Hill.

Popoola, B. A., Chinomona, R., \& Chinomona, E. (2014). The Influence Of Information Quality, System Quality And Service Quality On Student's Self-Efficacy At Institutions Of Higher Learning In South Africa. Mediterranean Journal Of Social Sciences, 5(27), 974984.

Pramana, I. G., \& Rastini, N. M. (2016). Pengaruh Kualitas Pelayanan Terhadap Kepercayaan Nasabah Dan Loyalitas Nasabah Bank Mandiri Cabang Veteran Denpasar Bali. E-Jurnal Manajemen Unud, 5(1), 706-733.

Risdyanto, A., Amelia, \& Ronald. (2018). Pengaruh Network Quality, Customer Service, Information Quality, Dan Security Terhadap Behavioural Loyalty Melalui Attitudinal Loyalty (Studi Kasus Pada First Media Di Surabaya). Jurnal Gema Aktualita, 7, 68-84.

Swa.co.id (2019, 24 Nov). Sociolla Ekosistem Kecantikan Dalam Satu Platfrom. Diakses pada 23 Juni 2020 , dari https://swa.co.id/youngster-inc/youngsterinc-startup/sociolla-ekosistem-kecantikan-dalam-satu-platform.

Umar, H. (2014). Faktor-Faktor Yang Memengaruhi Loyalitas Pelanggan Pada Penerbangan Low Cost Carrier. Jurnal Manajemen Transportasi \& Logistik (Jmtranslog), 1, 127-138.

Urbach, N., Smolnik, S., \& Riempp, G. (2010). An Empirical Investigation Of Employee Portal Success. Journal Of Strategic Information Systems , 19, 184-206.

Yan, T., \& Dooley, K. (2014). Buyer-Supplier Collaboration Quality In New Product Development Projects. Journal Of Supply Chain Management, 50(2), 59-83.

Yousuf, M. A., \& Wahab, E. B. (2017). The Role Of Trust In The Relationship Between Quality Factors And Customer Satisfaction In Mobile Banking: A Conceptual Framework. Medweel Journal The Social Sciences, 12, 712- 718 